Basic Medical Research

\title{
Role of allogenic mesenchymal stem cells in the reconstruction of bone defect in rabbits
}

\author{
Hadisoebroto D. Ismail, ${ }^{1}$ Phedy, ${ }^{1}$ Erica Kholinne, ${ }^{1}$ Achmad A. Jusuf, ${ }^{2}$ Nyimas D. Yulisa ${ }^{3}$ \\ ${ }^{1}$ Department of Orthopaedic and Traumatology, Faculty of Medicine, Universitas Indonesia, Jakarta, Indonesia \\ ${ }^{2}$ Department of Histology, Faculty of Medicine, Universitas Indonesia, Jakarta, Indonesia \\ ${ }^{3}$ Department of Radiology, Faculty of Medicine, Universitas Indonesia, Jakarta, Indonesia
}

\begin{abstract}
Abstrak
Latar belakang: Meskipun ada banyak penemuan baru untuk rekonstruksi tulang pada dekade terakhir, defek tulang luas tetap menjadi permasalahan di bidang ortopedi. Sel punca mesenkimal (SPM) muncul sebagai salah satu solusi yang berpeluang menangani masalah defek ini. Penelitian ini bertujuan mempelajari efektivitas transplantasi SPM dalam kombinasi dengan hidroksi apatit kalsium sulfat.
\end{abstract}

Metode: Dua puluh delapan kelinci secara acak dibagi ke dalam empat kelompok. Setiap kelompok mendapat perlakuan yang berbeda: otograf, hidroksiapatit kalsium sulfat (HA-CaSO ), HA-CaSO dikombinasikan dengan aspirat sumsum tulang, atau HA-CaSO dikombinasikan dengan $2 \times 10^{6} S P M$. Defek tulang panjang sepanjang $1 \mathrm{~cm}$ dibuat, dan langsung difiksasi dengan mini platescrew dan dua cerclage wires. Tindakan ini diikuti dengan transplantasi graft. Ketebalan kalus diukur dari rontgen yang dikerjakan pada minggu ke-4, -8, dan -12 setelah transplantasi oleh kedua peneliti secara independen. Pada akhir penelitian, pewarnaan histologi serta indeks osteosit diperoleh dengan mengorbankan kelinci. Data tersebut dianalisis dengan uji one-way ANOVA.

Hasil: Ketebalan kalus berbeda secara bermakna pada minggu ke-4 $(p=0,018)$. Walaupun tidak berbeda secara bermakna, kalus pada kelompok SPM di minggu ke-8 tampak lebih tebal daripada kelompok kontrol $(p=0,546)$. Kelompok SPM cenderung menunjukkan indeks osteosit yang lebih tinggi pada minggu keempat dan seterusnya.

Kesimpulan: Transplantasi SPM pada defek tulang menunjukkan formasi kalus yang lebih cepat, dan kalus yang lebih tebal.

\begin{abstract}
Background: Despite the advancement of bone reconstruction in the past decade, large bone defect remains a challenge for orthopedic surgery. As mesenchymal stem cells (MSCs) emerges as one of the possible treatment of these defects, we evaluate the effect of its transplantation, particularly in combination with hydroxyapatite-calcium sulphate pellets.
\end{abstract}

Methods: Twenty eight rabbits were randomly assigned into four different treatment groups. Each group received a different type of grafts (Autograft, hydroxyapatitecalcium sulphate $\left[\mathrm{HA}-\mathrm{CaSO} \mathrm{S}_{4}\right], \mathrm{HA}-\mathrm{CaSO}_{4}$ combined with marrow aspirate, or $\mathrm{HA}-\mathrm{CaSO}_{4}$ combined with $\left.2 \times 10^{6} \mathrm{MSCs}\right)$. One centimeter long bone defects were created then immediately fixated with mini plate-screw and two cerclage wires. It was followed by the graft transplantation. Callus thickness was measured from the $\mathrm{x}$-rays taken at 4, 8, 12 week after transplantation by two authors working independently. At the end of the study, histological staining along with osteocyte index were obtained by sacrificing the rabbits. These data were analyzed by one-way ANOVA test.

Results: At the fourth week, callus thickness showed significant difference $(\mathrm{p}=0.018)$. Although statistically insignificant, callus in MSCs group at the eighth week seemed to be thicker than any other groups of intervention $(p=0.546)$. The MSCs group also tend to have a higher osteocyte index at the follow-up weeks.

Conclusion: MSC transplantation on bone defect results in faster callus formation and tends to generate a thicker callus.

Keywords: bone defect, callus thickness, hydroxyapatite-calcium sulphate, mesenchymal stem cells, osteocyte index 
Bone defect remains a challenge for orthopaedic surgeons. It is often complicates fracture and necessitates additional reconstruction procedure. ${ }^{1}$ In our center, bone defect-related reconstruction procedures are required in $27 \%$ of all fracture cases.

Reconstruction of bone defect can be performed either by using autograft, allograft, or synthetic bone substitute. ${ }^{2,3}$ Autograft has a role as a scaffold and also induces bone healing. However, its availability for treating a large bone defect is very limited. Bone consolidation also occurs slower and causes significant donor site morbidity in some patients. ${ }^{1,3}$ Although allograft is readily available, it carries a higher risk of infection transmission rate, has a higher re-fracture rate, and is difficult to be remodeled. ${ }^{1}$ Synthetic bone substitute which created from undegradable materials impairs bone healing and tissue function. ${ }^{2}$ Conversely, the strength of degradable materials is still questionable and influenced by many factors. ${ }^{2}$

The advancement of tissue engineering has enabled us to isolate and expand mesenchymal stem cells (MSCs), cells that are capable to differentiate into osteoblast cells which is required in bone formation. ${ }^{4,5}$ Therefore it presents the possibility of MSCs to be applied in reconstruction of bone defect. In our study, we evaluated the role of MSCs in reconstruction of bone defect in animal model.

\section{METHODS}

This prospective randomized trial was performed from December 2009 until November 2010 in the Histology laboratory and animal house, Faculty of Medicine, Universitas Indonesia. Prior to the study, ethical approval was obtained from Ethics Committee of Faculty of Medicine, Universitas Indonesia. Based on Steel and Torrie formula, twenty eight giant Flemish rabbits weighted 2.70 $\mathrm{kg}$ were randomly assigned into four intervention groups. Each group received a different type of graft (Autograft, hydroxyapatite-calcium sulphate [HA$\mathrm{CaSO}_{4}$ ], $\mathrm{HA}-\mathrm{CaSO}_{4}$ combined with marrow aspirate, or $\mathrm{HA}-\mathrm{CaSO}_{4}$ combined with $2 \times 10^{6} \mathrm{MSCs}$ ).

\section{Surgical procedure}

Study animals were anesthesized using ketamine (35 mg per kilograms body weight). Defect of one centimeter long was created then immediately fixated with mini plate-screw. To enhance the strength of fixation, we added two extra cerclage wires.
The defects were then transplanted with the bone graft, which type is according to their allocated groups. Autograft was graft taken from the iliac wing, while marrow aspirate was aspirated from iliac marrow.

\section{Mesenchymal stem cells preparation}

Prior to surgical procedure, MSCs from seven donor Giant Flemish rabbits were isolated from the iliac crest using the same technique that was used before. ${ }^{6}$ The cells were seeded into $25 \mathrm{~cm}^{2}$ culture flask containing low-glucose Dulbelcco's Modified Eagles Medium (DMEM, Gibco, Green Island, New York) containing $10 \%$ fetal bovine serum and cultured at $37^{\circ} \mathrm{C}$ in $20 \% \mathrm{O}_{2}$ and $5 \% \mathrm{CO}_{2}$. Then the cells were subcultured into the first passage in $75 \mathrm{~cm}^{2}$ tissue culture flask. The culture reached confluence in 8 weeks. At the time of transplantation, two pellets of hydroxyapatite-calcium sulphate (Perossal ${ }^{\circledR}, \mathrm{GmBH}$, Germany) were soaked into the medium containing two millions of MSCs for one minute.

\section{Evaluation of stem cells compatibility with hydroxyapatite-calcium sulphate}

$\mathrm{HA}-\mathrm{CaSO}_{4}$ pellet was added into one of the cells culture. We observed the dissolution of the pellet and the growth of the cells every week under inverted microscope. After three weeks, the pellet was removed and the cell's growth was observed further for another week.

\section{Callus thickness}

The experimental animals underwent an x-ray examination every four week until twelve week post intervention. From the digital radiographs, the callus thickness at the proximal, central, and distal of the defect were measured using caliper by two independent authors who are blinded to the treatment allocation. The average of the thickness of the callus at the proximal, central, and distal of the defect defined as the callus thickness.

\section{Osteocyte index}

The experimental animals were sacrificed after 12 weeks. After the removal of the implant, the bones were decalcified and embedded in paraffin. Longitudinally oriented section of $5 \mu \mathrm{m}$ was placed on silane-coated slides and stained using tolluidine blue. The lacunae, both with and without osteocyte, were counted in three high power fields at the middle of the 
defect. The percentage of the lacunae with osteocytes to those without osteocytes defined as osteocyte index.

\section{Statistical analysis}

Callus thickness was analyzed using one-way ANOVA with Tukey HSD as the post-hoc analysis. Due to the small sample size, osteocyte index could not be analyzed statistically and presented descriptively.

\section{Ethical clearance}

The ethical clearance was acquired from the Research Ethic Committee of Faculty of Medicine, Universitas Indonesia. (No. 288/PT02.FK/ETIK/2009).

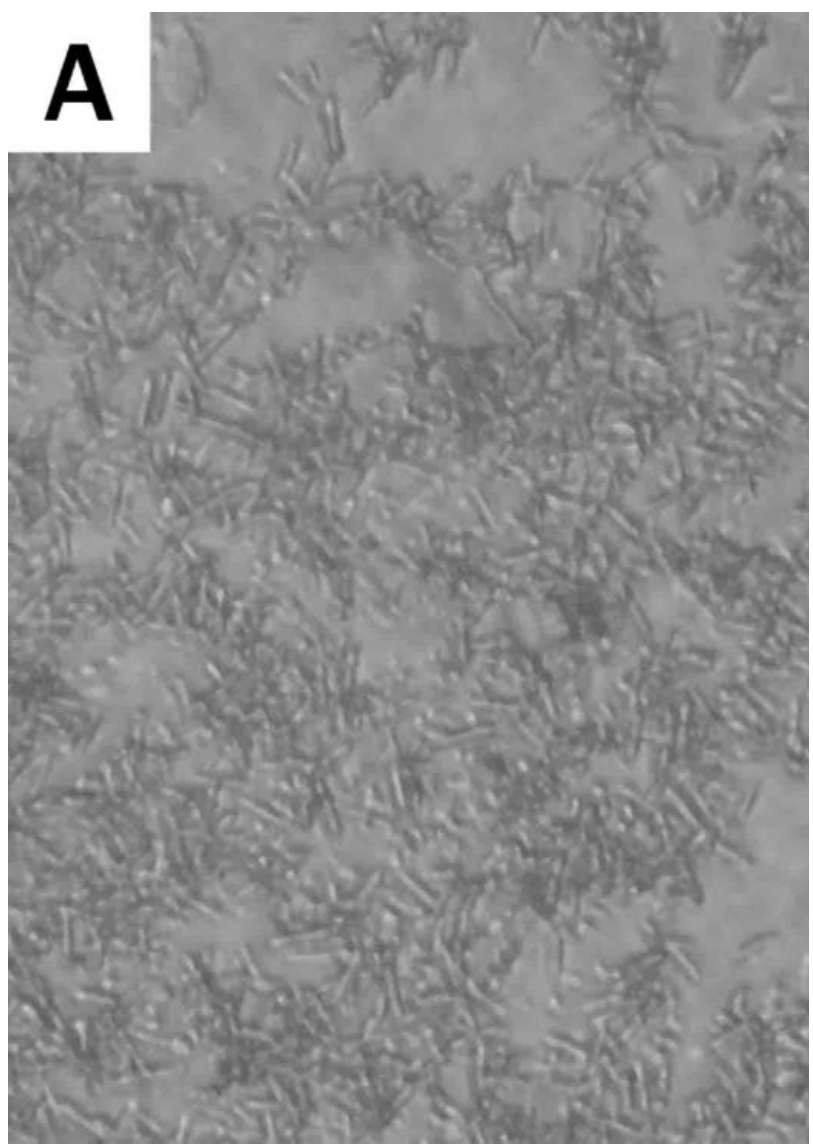

\section{RESULTS}

At eight week, confluence was achieved and more than 60 million cells were yielded from each flask. In the culture medium, $\mathrm{HA}-\mathrm{CaSO}_{4}$ pellet dissolved into crystals (Figure 1). These crystals would be washed out by changing the culture medium and would not interfered with cells growth.

The mean weight of the animal evaluated was 2695 $\pm 596.84 \mathrm{~g}$ and the femoral length was $12.3 \pm 1.3$ $\mathrm{cm}$. The characteristics of the evaluated animal are shown in table 1.

During our study, many animals did not survive due to diarrhea outbreak. Evaluable animals are

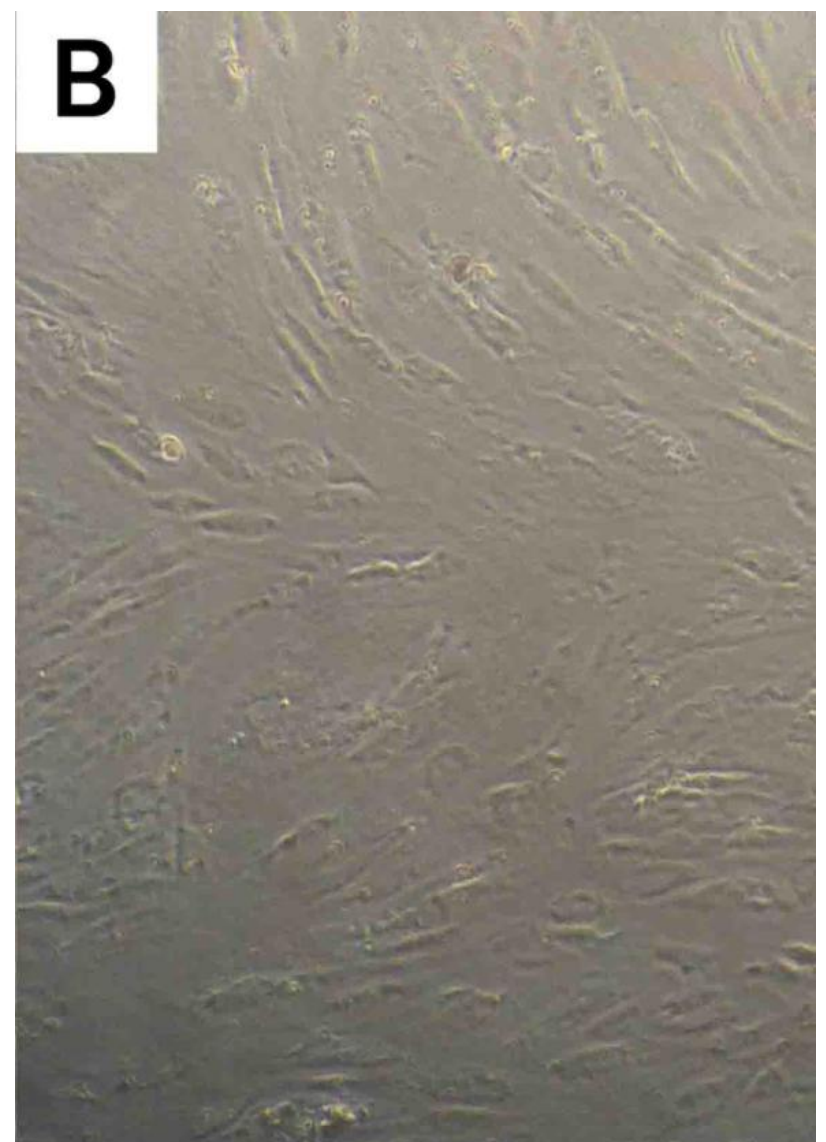

Figure 1. Hydroxyapatite-calcium sulphate dissolved in culture medium. A. During the first week, the crystals filled up the culture area and cells were hardly visible under microscope. B. At the fourth week, after the removal of the pellets, the cells were still viable

Table 1. Baseline characteristics of the animal

\begin{tabular}{lccccc}
\hline Characteristics & $\begin{array}{c}\text { Autograft } \\
(\mathrm{n}=7)\end{array}$ & $\begin{array}{c}\mathrm{HA}^{-C a S O}{ }_{4} \\
(\mathrm{n}=7)\end{array}$ & $\begin{array}{c}\mathrm{HA}^{-C a S O}{ }_{4}^{+} \\
\text {aspirate }(\mathrm{n}=7)\end{array}$ & $\begin{array}{c}\mathrm{HA}^{-C a S O}{ }_{4}^{+} \\
\mathrm{MSCs}_{(\mathrm{n}=7)}\end{array}$ & $\mathrm{p}^{*}$ \\
\hline Body Weight $(\mathrm{g})$ & $2786 \pm 486$ & $2743 \pm 753$ & $2771 \pm 599$ & $2373 \pm 518$ & 0.525 \\
Femoral anatomical length $(\mathrm{cm})$ & $9.1 \pm 0.8$ & $9.4 \pm 0.6$ & $9.2 \pm 0.8$ & $9.2 \pm 0.6$ & 0.833 \\
Femoral width $(\mathrm{mm})$ & $6.8 \pm 1.3$ & $6.9 \pm 1.4$ & $6.5 \pm 1.2$ & $6.6 \pm 1.2$ & 0.943 \\
\hline
\end{tabular}

$\mathrm{HA}-\mathrm{CaSO}_{4}$ : hydroxyapatite-calcium sulphate, MSCs: mesenchymal stem cells 
described in table 2. The diarrhea occurrence was found not related to mesenchymal stem cells $(\mathrm{p}=1)$ nor $\mathrm{HA}_{-} \mathrm{CaSO}_{4}(\mathrm{p}=0.318)$.

Between four intervention groups, only callus thickness at the week 4 showed statistically significant difference (Figure 2). Figure 3 shows radiographs of animals from the MSCs group.

Osteocyte index also tended to be higher in MSCs group although we were unable to perform statistical analysis due to the lack of sample (Figure 4).

Table 2. Number of evaluable animal during 12 weeks observation period

\begin{tabular}{lcccc}
\hline & Week & Week & Week & Week \\
& 1 & 4 & 8 & 12 \\
\hline Autograft & 7 & 5 & 4 & 4 \\
$\mathrm{HA}_{-} \mathrm{CaSO}_{4}$ & 7 & 5 & 3 & 0 \\
$\mathrm{HA}^{-} \mathrm{CaSO}_{4}+$ Aspirate & 7 & 6 & 5 & 2 \\
$\mathrm{HA}^{-\mathrm{CaSO}_{4}+\text { MSCs }}$ & 7 & 5 & 4 & 3 \\
\hline
\end{tabular}

$\mathrm{HA}^{-\mathrm{CaSO}_{4}}$ : hydroxyapatite-calcium sulphate, MSCs: mesenchymal stem cell

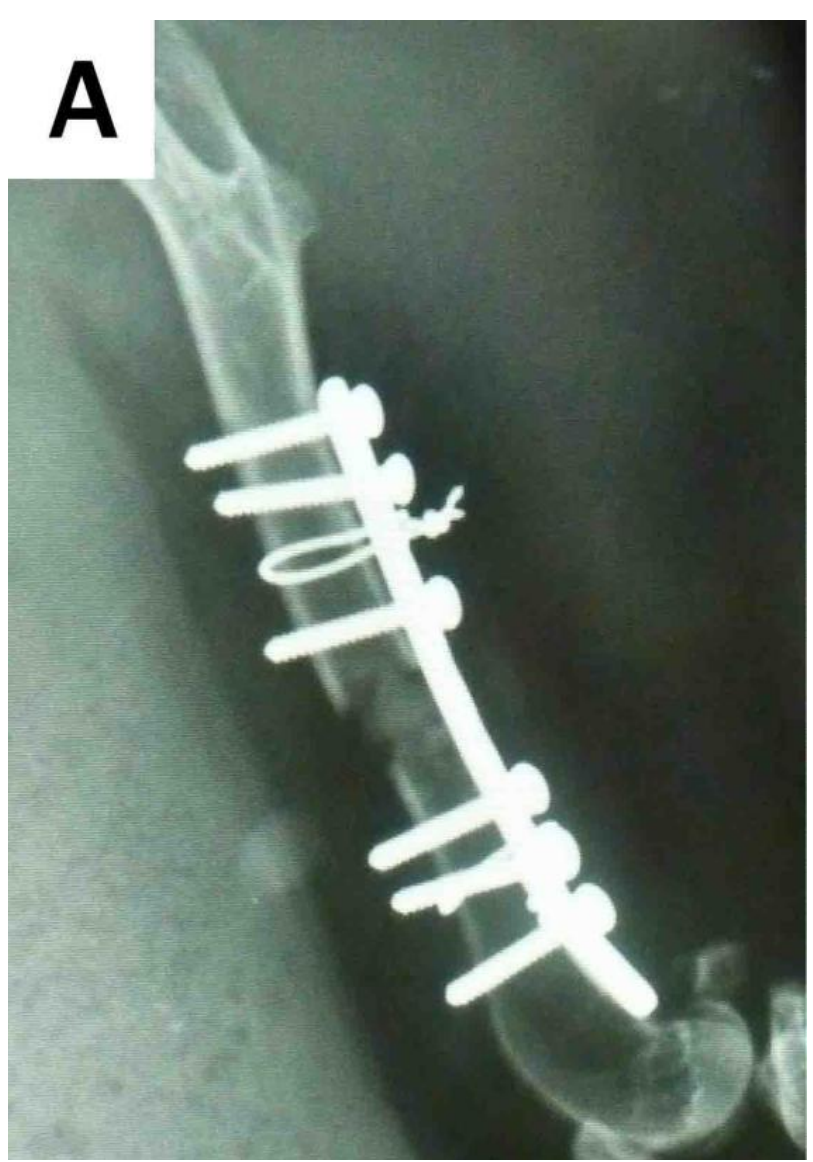

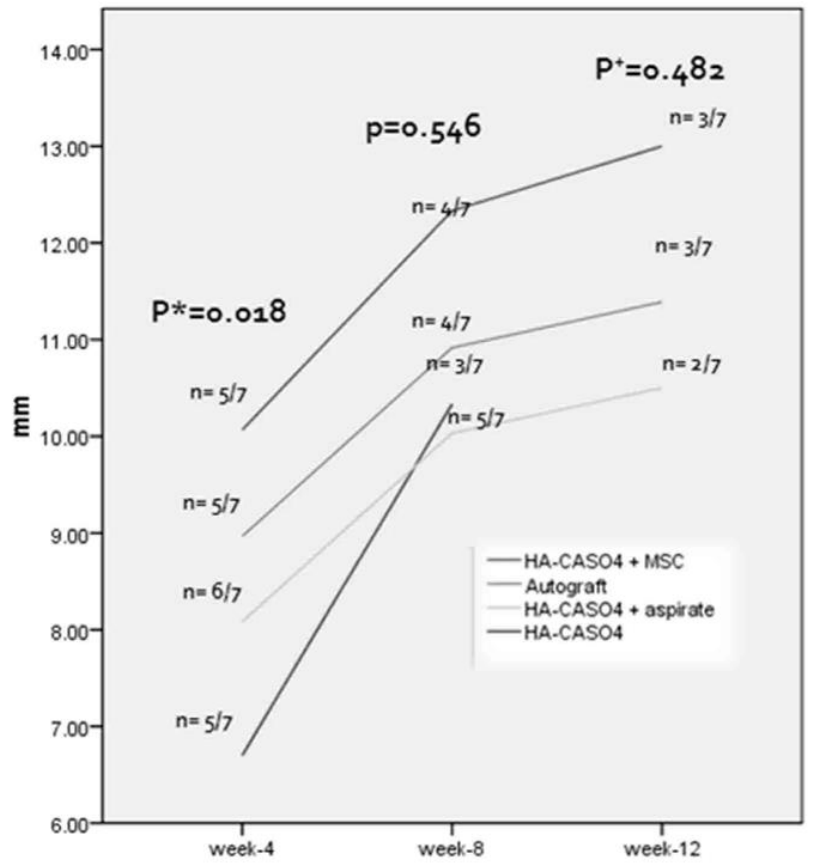

Figure 2. Callus thickness at the fourth, eighth and twelfth week. $p$ value at week 4 and 8 was determined using ANOVA test and at week 12 using Kruskal-wallis test. The difference of the callus thickness at week 4 was due to the difference between the HA-Ca$\mathrm{SO}_{4}$ and the $\mathrm{HA}-\mathrm{CaSO}_{4}+\mathrm{MSCs}$ group. (Tukey HSD p $=0.018$ )

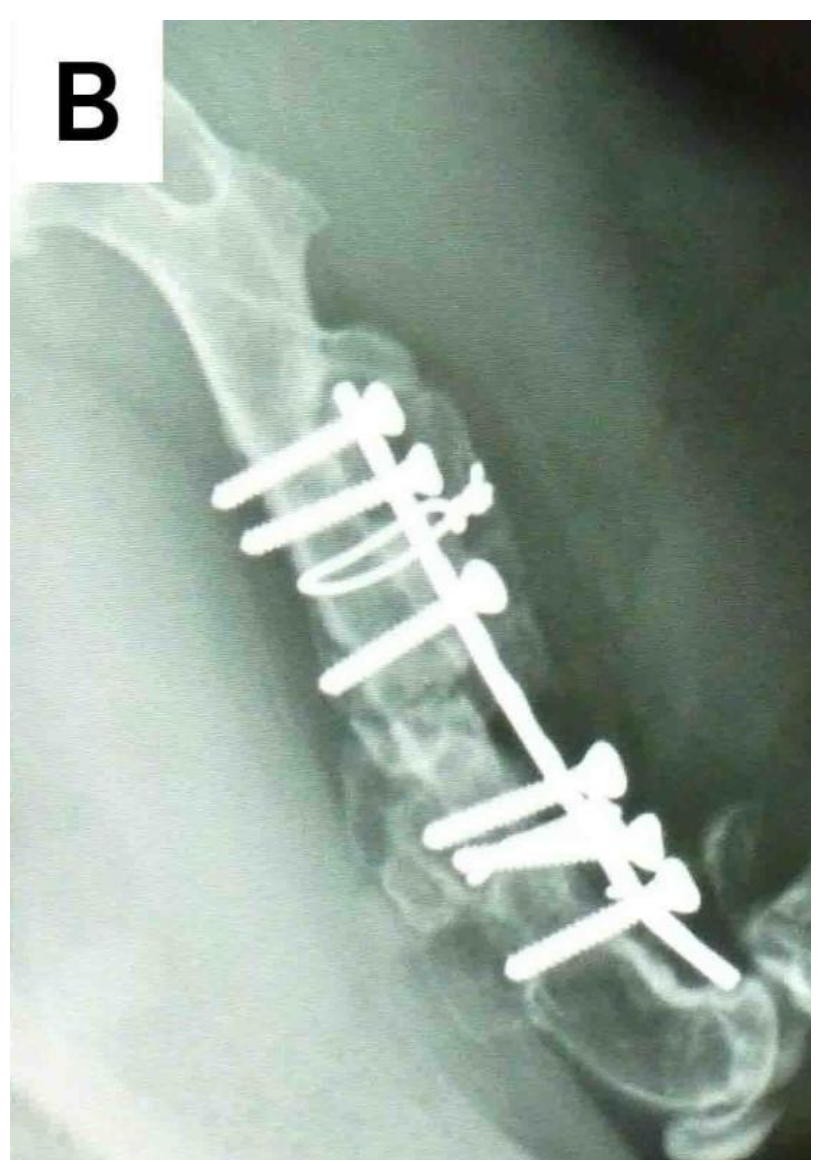

Figure 3. Defect with one centimeter of bone lost treated with combination of $\mathrm{HA}-\mathrm{CaSO}_{4}$ combined with MSCs. A. By the first week, no significant callus was formed. B. by the twelfth week, abundant callus was formed and fracture line was hardly visible 


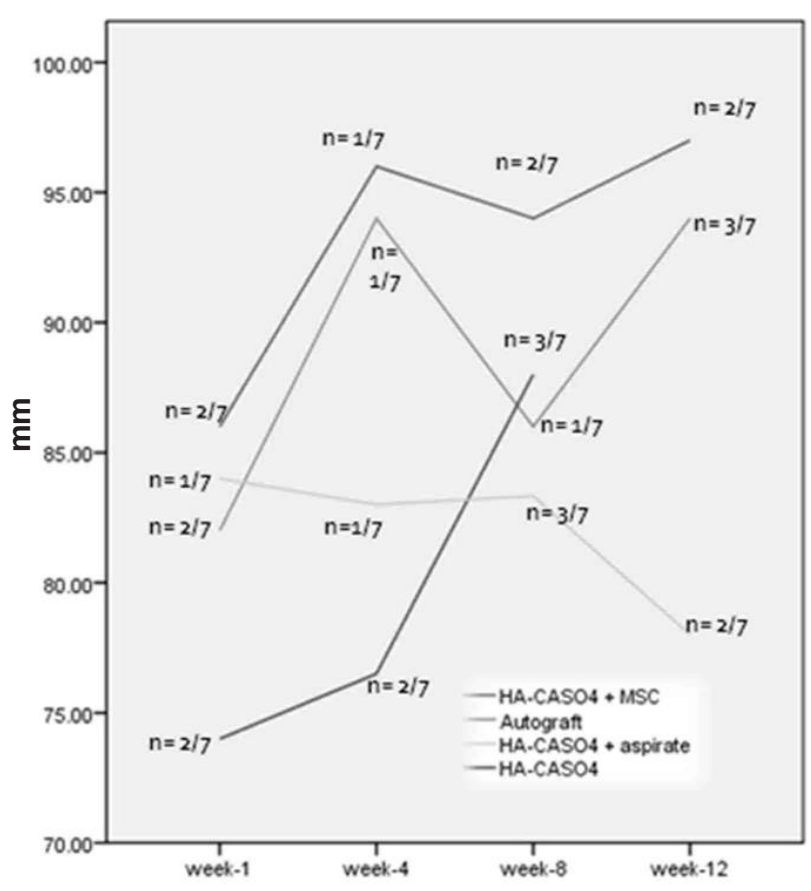

Figure 4. Osteocyte index at week 1, 4, 8 and 12. Osteocyte index tend to be highest amongst other groups at all period of evaluation

\section{DISCUSSION}

Osteoconductive scaffold is one of the components of diamond model in fracture healing, especially in bone defect. ${ }^{7}$ Hydroxyapatite, a crystalline scaffold, is seldom used alone due to its slow resorption and slow bone formation. ${ }^{8}$ Calcium sulphate, being rapidly resorbed, had been advocated by some authors to be used as osteoconductive scaffold. ${ }^{9}$ However, a study reported that calcium sulphate, if used alone, would have showed some citotoxic effects. ${ }^{10}$ We therefore used combination of the hydroxyapatite and calcium sulphate as the scaffold. The combination had a specific surface of $106 \mathrm{~m}^{2} / \mathrm{g}$ and had been reported to show no significant in vitro cytotoxic differences compared to nontoxic cell culture medium. ${ }^{10}$ Our result at the first phase of the study confirmed this report.

It took longer time to achieve confluence in our study compared to other studies. Medium type and seeding density had been reported to influence MSCs growth, although the best medium type and seeding density remain a controversy. ${ }^{11,12}$ Rapid expansion after initial seeding was reported in a commercial serum-free culture medium, however it failed to maintain the rate after subsequent passages. ${ }^{13}$ Refreshing only a part of the culture medium was also recommended by some authors. ${ }^{11}$

Although not addressed in our study, long term culture of MSCs might subject to Hayflick limit. ${ }^{14}$ The proliferation rate decayed, the cell sized increased, and the differentiation potential was affected, chromosomal instabilities arose, and molecular changed were acquired. The malignant transformation of long cultured MSCs remains a controversy and need further exploration. ${ }^{15,16}$

We compared the potency of MSCs with several other methods of treatment of bone lost, including autograft as the gold standard. In order to avoid bias, we also evaluated and compared the result with transplantation of the scaffold alone, the HA-CaSO${ }_{4}$ and also HA$\mathrm{CaSO}_{4}$ in combination with marrow aspirate.

Diarrhea outbreaks caused many death of the animal since the fourth week. Since the outbreaks occurred in every intervention group, we could not attribute the diarrhea to occur due to specific kind of cause.

We used callus thickness as the outcome in the present study. Callus growth is an indicator of healing process and have been used to quantify fracture healing. ${ }^{17}$ The result was confirmed further with histological evaluation using osteocyte index. Osteocyte index resembles cellular activity. ${ }^{18}$ The higher the cellular activity, the more likely the graft will survive.

Callus formation started at the first week of intervention. However, the formation was unreliable as indicated by considerable standard deviation. They also varied insignificantly between groups of intervention. This finding is relevant to the first healing phase of fracture. ${ }^{19}$ The first phase is marked by the hematoma formation and the resorption of the bone. No callus formation was found during this phase.

The second phase is the callus formation. ${ }^{19}$ Callus is initially liquid in consistency and slowly solidify and become readily visible in radiological imaging. This phase is in accordance to our finding at the fourth week. Reliable callus had been formed, particularly in the MSCs group. This finding can be explained from the fact that although osteoblast cells are readily available in bone, the new bone formation (callus) is mediated from the differentiation of progenitor cells which formed new osteoblast that are in charge for the callus formation. ${ }^{20}$

By the eight week, no significant difference was found between the intervention groups statistically. At this period, we believed that the amount of new osteoblast cells that have been formed is quite enough in every intervention groups. Although statistically insignificant, callus in MSCs group seemed to be thicker than any other groups of intervention. 
At the twelfth week, only three groups of intervention could be analyzed. We noticed that callus thickness in the MSCS group was thinner than the thickness at eighth week. We proposed that remodeling phase might have taken place.

Although our result shows promising role of MSCs, it should be noticed that our sample size was not adequate especially in the twelfth week. Most of the samples were injured by the diarrhea outbreak. Since the measurement of callus thickness is subjective, it was measured by two independent authors.

In summary, we conclude that MSC transplantation on bone defect results significantly faster callus formation and tend to generate a thicker callus.

\section{Acknowledgment}

We would like to express our appreciation to Research and Nuryati Chaerani Siregar, PhD for her support in completing this study, Mr. Dino from the Department of Histology for his assistance in taking care of the experimental animals, Ms. Ikke from the Department of Histology for her assistance in preparing tissue staining, Mr. Syuchinar Mega from the Department of Radiology for his assistance in performing digital x-ray, Mr. Budi and Arum, $\mathrm{PhD}$ from the Institute of Human Virology and Cancer Biology of the Universitas Indonesia for the technical assistance in preparing the mesenchymal stem cells.

\section{Conflict of interest}

This research was funded by Directorate of Research and Community Service Universitas Indonesia (DRPM-UI) and Faculty of Medicine of Universitas Indonesia. The funding source did not play role in the investigation.

\section{REFERENCES}

1. Arinzeh TL, Peter SJ, Archambault MP, van den Bos C, Gordon S, Kraus K, et al. Allogenic mesenchymal stem cells regenerate bone in a critical-sized canine segmental defect. J Bone Joint Surg Am. 2003;85A(10):1927-35.

2. Muschler GF, Nakamoto C, Girrfith LG. Engineering principles of clinical cell-based tissue engineering. J Bone Joint Surg Am. 2004;86A(7):1541-58.

3. DeCoster TA, Gehlert RJ, Mikola EA, Pirela-Cruz MA. Management of posttraumatic segmental bone defects. J Am Acad Orthop Surg. 2004;12(1):28-38.

4. Bruder SP, Jaiswal N, Ricalton NS, Mosca JD, Kraus $\mathrm{KH}$, Kadiyala S. Mesenchymal stem cells in osteobiology and applied bone regeneration. Clin Orthop Relat Res. 1998;355S:S247-56.

5. Lee EH, Hui JHP. The potential of stem cells in orthopaedic surgery. J Bone Joint Surg Br. 2006;88(7):841-51.

6. Hee HT, Ismail HD, Lim CT, Goh JC, Wong HK. Effects of implantation of bone marrow mesenchymal stem cells, disc distraction and combined therapy on reversing disc degeneration of the intervertebral disc. J Bone Joint Surg Br. 2010;92(5):726-36.

7. Gainnoudis PV, Einhorn TA, Marsh D. Fracture healing: the diamond concept. Injury. 2007;38(Suppl 4):S3-6.

8. De Long WG Jr, Einhorn TA, Koval K, McKee M, Smith W, Sanders R, et al. Bone grafts and bone graft substitutes in orthopaedic trauma surgery. A Critical analysis. J Bone Joint Surg Am. 2007;89(3):649-58.

9. Kelly CM, Wilkins RM, Gitelis S, Hartjen C, Watson JT, Kim PT. The use of a surgical grade calcium sulfate as a bone graft substitute: results of a multicenter trial. Clin Orthop Rel Res. 2001;382:42-50.

10. Rauschmann MA, Wichelhaus TA, Stirnal V, Dingeldein E, Zichner L, Schnettler R, et al. Nanocrystalline hydroxyapatite and calcium sulphate as biodegradable composite carrier material for local delivery of antibiotics in bone infections. Biomaterials. 2005;26(15):2677-84.

11. Both SK, van der Muijsenberg AJ, van Blitterswijk CA, de Boer $\mathrm{J}$, de Bruijn JD. A rapid and efficient method for expansion of human mesenchymal stem cells. Tissue Eng. 2007;13(1):3-9.

12. Colter DC, Class R, DiGirolamo CM, Prockop DJ. Rapid expansion of recycling stem cells in cultures of plastic-adherent cells from human bone marrow. PNAS. 2000;97(7):3213-8.

13. Pal R, Hanwate M, Jan M, Totey S. Phenotypic and functional comparison of optimum culture conditions for upscaling of bone marrow-derived mesenchymal stem cells. J Tissue Eng Regen Med. 2009;3(3):163-74.

14. Wagner W, Bork S, Lepperdinger G, Joussen S, Ma N, Strunk D, et al. How to track cellular aging of mesenchymal stromal cells? Aging. 2010;2(4):224-30.

15. Røsland GV, Svendsen A, Torsvik A, Sobala E, McCormack E, Immervoll H, et al. Long-term cultures of bone marrowderived human mesenchymal stem cells frequently undergo spontaneous malignant transformation. Cancer Res. 2009;69(13):5531-9.

16. Bernardo ME, Zaffaroni N, Novara F, Cometa AM, Avanzini MA, Moretta A, et al. Human bone marrow-derived mesenchymal stem cells do not undergo transformation after long-term in vitro culture and do not exhibit telomere maintenance mechanisms. Cancer Res. 2007;67(19):9142-9.

17. Eastaugh-Waring SJ, Joslin CC, Hardy JR, Cunningham JL. Quantification of fracture healing from radiographs using the maximum callus index. Clin Orthop Relat Res. 2009; 467(8):1986-91.

18. Nather A, David V, Teng JW, Lee CW, Pereira BP. Effect of autologous mesenchymal stem cells on biological healing of allografts in critical-sized tibial defects stimulated in adult rabbits. Ann Acad Med Singapore. 2010;39(8):599-606.

19. Salter RB. Fractures and joint injuries-general features. In: Salter RB, ed. Textbook of disorders and injuries of the musculoskeletal system. Third ed. Maryland: William\&Wilkins; 1999. p. 417-97.

20. Yoo JU, Johnstone B. The role of osteochondral progenitor cells in fracture repair. Clin Orthop Relat Res. 1998;355S:S73-81. 